\section{Are my patients with rheumatic diseases at higher risk of COVID-19?}

According to the last WHO situation report (10 March 2020), the novel Coronavirus disease 2019 (COVID-19) has been confirmed in 113702 patients, most of them in China (71.1\%) and the rest in other 109 countries, with a global case-fatality rate (CFR) of 3.5\% (4012 deaths among 113702 confirmed cases). ${ }^{1}$ Most patients have presented with fever, dry cough and fatigue, about $81 \%$ of cases reported in China have been classified as mild, 14\% severe and 5\% critical, the higher CFR has been observed among older patients and with comorbid conditions (cardiovascular disease, diabetes, chronic respiratory disease, hypertension, cancer, etc). ${ }^{2}$ To our knowledge none of the fatal cases reported has been associated with rheumatic diseases.

Patients with rheumatic diseases are known to be at higher risk of infection attributed to disease activity, comorbidities, immunosuppressive therapy, etc. ${ }^{3}$ The WHO promotes that the general population take some basic protective measures against COVID-19 and other respiratory viruses that include: frequent hand washing; social distancing (at least $1 \mathrm{~m}$ between the patient and anyone who is coughing or sneezing); reducing face touching and respiratory hygiene practices such as covering mouth and nose with bent elbow or tissue when coughing or sneezing. If there is fever, cough and shortness of breath, medical care should be sought early. All these measures must also be employed and promoted by healthcare workers.

In a recent study, chloroquine showed potent in vitro antiviral effect in a COVID-19 assay by increasing endosomal $\mathrm{pH}$ that is required for virus/cell fusion as well as interfering with glycosylation of cellular receptors, ${ }^{4}$ adding its well-known immunemodulating action. Chloroquine is being considered to be included in the next version guidelines for the prevention, diagnosis and treatment of pneumonia caused by COVID-19 issued by the National Health Commission of the People's Republic of China. ${ }^{5}$

Based on the clinical information published to date from the new and previous outbreaks caused by coronaviruses (severe acute respiratory syndrome and Middle East respiratory syndrome), there is no overwhelming evidence that patients with rheumatic diseases are at an increased risk compared with other comorbidities. ${ }^{26}$ Although further information regarding this outbreak need to surface before any solid conclusion can be made. We believe that based on the knowledge of other viral infections and the effect of the therapies used in rheumatic patients leads us to think that there is an increased probability for this population to acquire COVID-19. In counterpart, there is also some evidence of the potential benefit of a drug widely used in rheumatic diseases: chloroquine. Only time and the directed clinical trials will clarify the prophylactic or therapeutic role of chloroquine and its effect on the risk of COVID-19 in rheumatic patients.
Gabriel Figueroa-Parra $\odot,{ }^{1}$ Gloria Mayela Aguirre-Garcia, ${ }^{2}$

Carmen Magdalena Gamboa-Alonso, ${ }^{1}$ Adrian Camacho-Ortiz, ${ }^{2}$ Dionicio Angel Galarza-Delgado ${ }^{1}$

'Servicio de Reumatología, Hospital Universitario "Dr José Eleuterio González", Universidad Autónoma de Nuevo León, Monterrey, Mexico

${ }^{2}$ Servicio de Infectología, Hospital Universitario "Dr José Eleuterio González", Universidad Autónoma de Nuevo León, Monterrey, Mexico

Correspondence to Dionicio Angel Galarza-Delgado, Servicio de Reumatología, Hospital Universitario Dr Jose Eleuterio Gonzalez, 64460 Monterrey, Mexico; dgalarza@medicinauanl.mx

\section{Handling editor Josef S Smolen}

Contributors GF-P and GMA-G conceived the manuscript. GF-P, GMA-G, CMG-A, AC-O, DAG-D, drafted and revised the manuscript for important intellectual content.

Funding The authors have not declared a specific grant for this research from any funding agency in the public, commercial or not-for-profit sectors.

Competing interests None declared.

Patient and public involvement Patients and/or the public were not involved in the design, or conduct, or reporting, or dissemination plans of this research.

Patient consent for publication Not required.

Provenance and peer review Not commissioned; internally peer reviewed.

This article is made freely available for use in accordance with BMJ's website terms and conditions for the duration of the covid-19 pandemic or until otherwise determined by BMJ. You may use, download and print the article for any lawful, non-commercial purpose (including text and data mining) provided that all copyright notices and trade marks are retained.

(c) Author(s) (or their employer(s)) 2020. No commercial re-use. See rights and permissions. Published by BMJ.

GF-P and GMA-G contributed equally.

Check for updates

To cite Figueroa-Parra G, Aguirre-Garcia GM, Gamboa-Alonso CM, et al. Ann Rheum Dis 2020;79:839.

Received 11 March 2020

Accepted 15 March 2020

Published Online First 22 March 2020

Ann Rheum Dis 2020;79:839. doi:10.1136/annrheumdis-2020-217322

ORCID iD

Gabriel Figueroa-Parra http://orcid.org/0000-0002-6077-8899

\section{REFERENCES}

1 WHO. Novel coronavirus (2019-nCoV) situation reports. Available: https://www. who. int/emergencies/diseases/novel-coronavirus-2019/situation-reports [Accessed $11 \mathrm{Mar}$ 2020].

2 Wu Z, McGoogan JM. Characteristics of and important lessons from the coronavirus disease 2019 (COVID-19) outbreak in China: summary of a report of 72314 cases from the Chinese center for disease control and prevention. JAMA 2020.

3 Meroni PL, Zavaglia D, Girmenia C. Vaccinations in adults with rheumatoid arthritis in an era of new disease-modifying anti-rheumatic drugs. Clin Exp Rheumatol 2018;36:317-28.

4 Wang $M$, Cao R, Zhang L, et al. Remdesivir and chloroquine effectively inhibit the recently emerged novel coronavirus (2019-nCoV) in vitro. Cell Res 2020;30:269-71.

5 Gao J, Tian Z, Yang X. Breakthrough: chloroquine phosphate has shown apparent efficacy in treatment of COVID-19 associated pneumonia in clinical studies. Biosci Trends 2020;14:72-3.

6 Guan W-jie, Ni Z-yi, Hu Y, et al. Clinical characteristics of coronavirus disease 2019 in China. N Engl J Med 2020. 